\title{
EVALUATING THE PERFORMANCE OF COLOMBIAN BANKS BY HYBRID MULTICRITERIA DECISION MAKING METHODS
}

\author{
Amir Karbassi YAZDI ${ }^{\circledR 1}{ }^{1}$, Thomas HANNE ${ }^{\circledR 2}{ }^{*}$, Juan Carlos OSORIO GÓMEZ ${ }^{\circledR 3}$ \\ ${ }^{1}$ Young Researchers and Elite Club, South Tehran Branch, Islamic Azad University, Tehran, Iran \\ ${ }^{2}$ Institute for Information Systems, University of Applied Sciences and \\ Arts Northwestern Switzerland, Olten, Switzerland \\ ${ }^{3}$ Escuela de Ingeniería Industrial, Universidad del Valle, Cali, Colombia
}

Received 02 October 2018; accepted 23 October 2019

\begin{abstract}
The aim of the study in this paper is to show how the performance of banks can be evaluated by ranking them based on Balanced Scorecard (BSC) and Multicriteria Decision Making (MCDM) methods. Nowadays, assessing the performance of companies is a vital work for finding their weaknesses and strengths. The banking sector is an important area in the service sector. Many people want to know which bank performs best when entrusting their money to them. For assessing the performance of banks, BSC can be used. This method helps to translate strategic issues to meaningful insights for the respective financial institutions. After that, the banks will be ranked based on performance indicators by the Weighted Aggregated Sum Product Assessment (WASPAS) method. Because this method is based on a decision matrix, weights are required. To find such weights, the Step-wise Weight Assessment Ratio Analysis (SWARA) method is applied. The results show that the International Bank of Colombia has a much better performance than other Colombian banks. Besides, further insights regarding the evaluation process based on BSC, SWARA, and WASPAS are obtained.
\end{abstract}

Keywords: weighted aggregated sum product assessment, step-wise weight assessment ratio analysis, balanced scorecard, performance evaluation, multicriteria decision analysis, banking sector.

JEL Classification: C44.

\section{Introduction}

Nowadays, many factors affect the performance of banks. One of the most important is globalization (Claessens \& Horen, 2014), which induced many banks to revise their performances and try to improve them. As a result of globalization, many customers want the same services they would get from outstanding banks, and they prefer to use services based on state-of-the-art technologies (Lerner et al., 2018).

${ }^{\star}$ Corresponding author. E-mail: thomas.hanne@fhnw.ch 
For these reasons, many researchers have published studies on the performances of banks (LaPlante \& Paradi, 2015; Shafiee et al., 2016; Sun et al., 2017). Moreover, many banks attempt to increase their performance. Many private banks aim at entering foreign markets and gain market shares in the respective countries. To attract customers, they invest in advanced technologies and provide improved services. This leads to major challenges for domestic banking companies.

The Colombian banking sector is no exception to this rule. Based on a 2017 statistics of the World Bank, the economy of Colombia improves dramatically. The GDP increased from 4.04 billion dollars in 1960 to 282.46 billion dollars in 2016. In addition, the population size increased approximately from 16.5 million persons in 1960 to 48.6 million persons in 2016 . The rate of people living in poverty fell sharply from $49.7 \%$ in 2002 to $28 \%$ in 2016 . These developments show that the economic situation in Colombia improved drastically during these years. As a result, the number of interactions between customers and banks has increased as well.

The objective of this research is to assess and measure the performance of banks in order to rank them based on various indicators. This ranking helps customers get insights into the banks' performances and make a decision about entrusting their money to them. Another merit of this paper is that it provides a guide for banks to improve their performances and become excellent banks.

The aim of this paper is to prioritize six selected banks in Colombia, based on Performance Indicators (PIs). These performance indicators are obtained from a Balanced Scorecard (BSC) model. For ranking these PIs, a hybrid approach is used. As the main technique of ranking the Weighted Aggregated Sum Product Assessment (WASPAS) method is applied. As this method is a decision matrix method, weights must be determined for aggregating the different criteria. To obtain these weights, the Step-wise Weight Assessment Ratio Analysis (SWARA) method is used. Finally, banks are ranked based on these PIs, the obtained weights, and the Multicriteria Decision Making (MCDM) method WASPAS.

The contributions of this paper and the gap in the existing literature can be addressed as follows:

1. One of the original contributions is to suggest and use a hybrid model based on a combination of the SWARA and the WASPAS methods. Both metods are comparably easy-to-use, reliable, and are well suited for their combined application. An extensive literature search did not reveal any other paper dealing with the combination of these methods in the banking sector.

2. Another contribution of this paper is the case study on Colombian banks. There was no evidence of similar research on the performance measurement of banks in Colombia.

Thus, the paper addresses two research questions: How can the performance of Colombian banks be evaluated? Is it possibly to use both SWARA and WASPAS in a BSC context for performance measurement? The combined usage of both methods appears to be promising since SWARA provides a convenient and reliable way to asses criterion-specific weights, while WASPAS is a suitable tool to utilize such weights taking into account how the different criteria could be aggregated. 
The rest of the paper consists of these parts: After the introduction, a literature review on the banking industry and BSC is depicted. Section 2 illustrates MCDM methods. The research methodology is shown in Section 3. Section 4 concerns data analysis and presents the results of the application of the methods mentioned. In Section 5 managerial implications are discussed. In the final section, the conclusions are presented.

\section{Literature review}

\subsection{Banking industry}

The banking industry is one of the most important industries in the field of providing services to people. Everyday, numerous people require diverse banking services. Usually, in a country there are domestic and foreign banks with a strong competition among them. Therefore, the performance of banks is a popular topic among researchers. Approaches to assess the banking industry can be divided into two main categories. First, there are diverse kinds of studies based on Data Envelopment Analysis (DEA). Secondly, there are various studies that use MCDM methods. Let us note, that DEA and MCDM methods found wide areas of applications such as, for instance, for supplier selection (Beheshtinia \& Nemati-Abozar, 2017), for prioritizing renewable power plants' construction (Sedady \& Beheshtinia, 2019), or for evaluating the quality of hospital services (Torkzad \& Beheshtinia, 2019). However, in the following the literature review only considers respective studies in the field of banking.

The approaches based on DEA can be subdivided into four types. First, there is classic DEA which is mentioned in the follwing papers: Paradi and Zhu (2013) applied DEA for an analysis of the effienciency of banks. They found out that there were diverse inputs and outputs for assessing banks and they could mix the results of DEA with other methods. Emrouznejad and Anouze (2010) assessed the banks of the Persian Gulf Cooperation Council countries using DEA and classified them using a regression tree. The result showed which factors affected the efficiency of these banks. Another study is related to network DEA. Paradi et al. (2011) demonstrated a two-stage DEA method for bank branch efficiency analysis. They found out that small and medium branches were more efficient regarding both production and profitability. The final subcategory relates to applications of fuzzy data in DEA. Chen et al. (2013) assessed the performance of business banks by fuzzy DEA. They concluded that when data of inputs and outputs were not deterministic, they had to use fuzzy numbers and, in particular, triangular fuzzy numbers helped them solve the problem. As a fourth variant of DEA, let us mention that it became popular to use DEA in connection with Malmquist indicators which are traditionally used to compare two econmomies regarding their performance using a given production technology. For instance, Emrouznejad and Yang (2018) have found more than 300 publications dealing with DEA in combination with Malmquist indicators. Also in the field of banking such approaches are used occasionally, for instance in Asmild et al. (2004) where Candian banks were evaluated based on data from a 20 years period. In Van der Westhuizen (2008) the efficiency and causes for efficiency change were evaluated for the four largest banks in South Africa for a period of 36 months. Majumdar and Asgari (2017) studied the performance measurement of UAE companies by DEA Malmquist. They 
used labor, capital, materials, revenue and EPS as the inputs and outputs of the model. The result showed that the performance of these companies will increase because of advanced technology, investment and new production. Guo et al. (2017) evaluated hospitals performance of Hong Kong by DEA Malmquist and Tobit regression. Inputs and outputs of this research were the number of staff, the number of beds, the discharge rate, the length of stay, the total ED attendances, the total outpatient attendance, and the crude mortality rate. The result revealed that rich people like to receive better services in private hospitals. Wu et al. (2017) used DEA Malmquist for measuring energy and environment performance in China. Labor, capital, energy, GDP and waste gas were inputs and outputs of this study. The result demonstrated that most provinces had low energy and environmental efficiency.

The second category of approaches deals with using MCDM methods for both crisp and fuzzy data. Most researchers used MCDM methods with crisp data. In early publications using MCDM for the analysis of banks, mostly financial data such as those based on balance-sheet analysis were used, see, e.g., Hanne (1995), while later the set of criteria was expanded. Dash (2017) showed how the PROMETHEE method helps to create a model for the measurement of bank performance. He used the CAMEL method for extracting factors and then prioritized the banks based on these factors. Fallah Jelodar (2016) showed a model for prioritizing factors for bank efficiency by the combination of DEA and the Analytical Hierarchy Process. The result shows which banks are efficient and which are inefficient and also which factors are affected by the performance measurements. The second category deals with the applications of MCDM with fuzzy data. Akkoç and Vatansever (2013) demonstrate how the fuzzy Analytical Hierarchy Process (AHP) and the fuzzy TOPSIS (Technique for Order of Preference by Similarity to Ideal Solution) helped the Turkish bank sector to defeat the global financial crisis. The results obtained by both approaches were similar and led to the same ranking. Beheshtinia and Omidi (2017) assessed the performance of banks in Iran by a combination of fuzzy MCDM methods. They found out that some factors such as return on investment, debt ratio, and lower energy consumption were very important factors of a bank's performance. Shaverdi et al. (2011) used fuzzy MCDM methods together with BSC for the Iranian private banking sectors. The result showed that the customer's perspective was most important and that customer satisfaction was the most important performance measurement criterion in the study.

\subsection{Balanced scorecard}

There are various methods for evaluating companies. One of those is the ISO standard that is used in more than 70 countries. Total Quality Management (TQM) is another method for assessing companies. This method is based on the philosophy and concept of increasing customer satisfaction. Management by Objective $(\mathrm{MBO})$ is a third method that demonstrates how companies work to achieve objectives set before. Management by Values (MBV) points out all plans, make decision conducts based on value. The Malcom Baldrige National Quality Award is an annual prize for USA organizations that recognizes their efforts to achieve qualitative objectives. The aim of this award is increasing quality awareness as the important element of competitive strength and profit of organizations. Activity Based Costing (ABC) is the another method for evaluating companies. Using this method companies assess perfor- 
mance based on solely financial parameters while other parameters such as internal processes or HR are not considered. Hoshin Kanri is another method for evaluating companies (and performance programs of companies) based on a plan-do-check-act (PDCA) cycle. Data Envelopment Analysis (DEA) is a method of evaluating companies based on linear programming and related models based on inputs and outputs of a company. This method evaluates DMUs (decision making units) based on a score of inputs and outputs and then ranks them. As a result, it is shown which DMUs are efficient and which of them are inefficient. Table 1 shows the comparison of these methods. Due to some weaknesses in these approaches and because Balanced Scorecard is one of the most frequentsly used approaches for performance assessment, this methodology is considered in the following.

Table 1. Comparison of assessment methods

\begin{tabular}{|l|c|c|l|}
\hline \multicolumn{1}{|c|}{ Method } & Qualitative & Quantitative & Judgment in performance assessment \\
\hline ISO standard & $\checkmark$ & & Standard, Check List \\
\hline $\begin{array}{l}\text { Total Quality Management } \\
\text { (TQM) }\end{array}$ & $\checkmark$ & & Programms \\
\hline $\begin{array}{l}\text { Management by Objective } \\
\text { (MBO) }\end{array}$ & $\checkmark$ & & Objective, Checklist \\
\hline Management by Values (MBV) & $\checkmark$ & & Value, Checklist \\
\hline Activity Based Costing (ABC) & $\checkmark$ & $\checkmark$ & Financial Ratios \\
\hline Hoshin Kanri & $\checkmark$ & & PDCA cycle \\
\hline $\begin{array}{l}\text { Data Envelopment Analysis } \\
\text { (DEA) }\end{array}$ & & $\checkmark$ & $\begin{array}{l}\text { Linear Programming, Inputs and } \\
\text { Outputs }\end{array}$ \\
\hline
\end{tabular}

Balanced Scorecard (BSC) is a management framework that translates an organization's strategic objectives into a set of performance measures to be applied to customer, product, process and market development. From this model, people understand that using only financial performance measurements is insufficient for measuring the performance of an organization. Therefore, additional perspectives such as internal processes as well as learning and growth should be taken into account (Kaplan \& Norton, 1992). One of the merits of BSC is that it depicts cause and effect relationships among performance indicators (Kaplan \& Norton, 1996c). This model consists four dimensions:

1. Financial perspective: Before introducing BSC many companies evaluated the performance of their companies by financial indicators which show how successful they are in achieving their goals. Kaplan and Norton demonstrated that although financial indicators had an important role in the evaluation of companies they cannot solely ensure the achieement of goals and fulfilling the company vision. For reaching the financial targets many factors are needed.

2. Customer perspective: One of factors that effect financial indicators are customers indicators. Researchers understand that for increased targets of financial indicators such as profit, revenue, and so on they need to focus on customers and especially increase their loyalty and satisfaction. As a consequence financial indicators increased dramatically. 
3. Internal perspective: After recognizing the role of customers, companies attempted to increase the target of customers indicators. Meanwhile they understood that some internal factors have a significant effect on customer loyalty and satisfaction. These factors are reengineering, process management, supply chain management and so on. They can cause that work will be done with low total cost and within less time than before.

4. Learning and growth perspective: Many companies are looking forward to find out how improvement programs of the internal perspective can be successfully implemented. Often failures were observed during respective implementation projects. As a result of various studies, the key role staff during such projects was understood. Staff must be trained and care must be taken to overcome the possible resistance of improvement project implementations (Kaplan \& Norton, 1992, 1996a, 1996b).

After introducing BSC, many papers were published, most of them focusing on a combination of BSC with MCDM methods. One of the popular MCDM methods used in this field is the Analytical Hierarchy Process (AHP). To address this issue, Sundharam et al. (2013) used BSC and the AHP to analyze the growth of manufacturing industries. They showed that the combination of these two tools helped figure out which are the best factors to evaluate industries. Bentes et al. (2012) studied the assessment of organizational performance with BSC and AHP. They showed that AHP had some drawbacks and to eliminate them, a groupbased version of the AHP was used. Y. H. Kim and M. Kim (2010) created a new model for assessing websites by using BSC and AHP. They set CSFs (Critical Success Factors) for the evaluation of websites by BSC and prioritized them. The result showed that the customer perspective was the most important perspective. Another MCDM tool for ranking performance measurement of BSC is TOPSIS. Asli et al. (2013) used TOPSIS for prioritizing strategy planning and BSC. They discussed how factors for prioritization can be extracted, based on a combination of a strategy map and BSC. The term strategy map refers to a diagram that is used to document the primary strategic goals of an organization or management team and is characteristic for BSC approaches of the second generation. Sadeghi et al. (2013) applied grey TOPSIS and BSC for defining a strategy map. They illustrated how TOPSIS helped managers find out the most important factors of BSC. The Analytic Network Process (ANP) is another MCDM technique. Hu et al. (2015) pointed out how to measure knowledge resources by BSC and ANP. The result showed that this method contributed to clarifying the measurement of the performance of knowledge resources. Some papers were published which use a combination of fuzzy ANP and BSC. Bhattacharya et al. (2014) clarified how Green Supply Chain Management can be analyzed with fuzzy ANP and BSC. This model helped managers prioritize factors of Green BSC in manufacturing. Zolfani and Ghadikolaei (2013) combined DEMATEL, VIKOR and ANP with BSC to evaluate private universities in Iran. They showed that among four BSC perspectives the perspective of the internal processes is the most important one. Dincer and Hacioglu (2013) explained a model for the performance assessment of Turkish banks with fuzzy VIKOR, AHP and BSC. The result elucidated that private banks had higher performance levels than foreign banks. Sofiyabadi et al. (2016) evaluated the service business sectors by fuzzy VIKOR and BSC. From the combination of these two methods and the implementation in the company LG they concluded that this company 
should focus on the perspectives customer, learning and growth. One of the tools for creating strategy maps is DEMATEL. This method shows cause and effect relationships among factors. Valmohammadi and Sofiyabadi (2015) studied how one can create strategy maps of Iranian automobile companies by fuzzy DEMATEL and BSC. Kala and Bagri (2016) used DEMATEL for performance measurement of BSC for creating strategy maps of hotels. Varmazyar, Dehghanbaghi, and Afkhami (2016) explained how to use BSC and a hybrid MCDM model for the evaluation of research and technology organizations. They used DEMATEL, Additive Ratio Assessment (ARAS), Complex Proportional Assessment (COPRAS), Multi-Objective Optimization by Ratio Analysis (MOORA) and TOPSIS.

As mentioned before, the main contribution of this paper is the use of the SWARA and the WASPAS methods for ranking the performance of banks. For the WASPAS method, weights are required as preference-based information. There are many methods which contribute to finding these weights such as AHP, ANP and so on but when the number of items is increased beyond six items, the inconsistency rate rises significantly, which makes the finding of correct weights very difficult. Therefore, another method is required that does not have this drawback. The SWARA method is one of the methods which fulfils this purpose. There is no evidence of the use of these two methods for asessing the performance of banks in previous research. Table 2 indicates performance indicators used in the discussed research.

Table 2. Performance indicators of research

\begin{tabular}{|l|l|}
\hline \multicolumn{1}{|c|}{ PIs } & \multicolumn{1}{c|}{ Autor/Authors } \\
\hline Net profit & Ha and Yang (2017), Rabbani et al. (2014), Zhao and Li (2015) \\
\hline ROI & Fan et al. (2017), Rabbani et al. (2014) \\
\hline Debt & Bennett et al. (2017), Lee et al. (2018) \\
\hline Total cost & Kumar et al. (2017), Mwencha et al. (2017) \\
\hline Income & Curtis et al. (2018), Huang and Badurdeen (2017) \\
\hline Total assets & $\begin{array}{l}\text { Malagueño et al. (2018), Mehralian et al. (2017), Ozkan et al. } \\
\text { (2017) }\end{array}$ \\
\hline Customer satisfaction & $\begin{array}{l}\text { Bazrkar et al. (2017), Mehralian et al. (2017), Zahoor and } \\
\text { Sahaf (2018) }\end{array}$ \\
\hline Share market & Kerai and Saleh (2017), E. H. Nielsen and S. Nielsen (2018) \\
\hline Number of customers & Dinçer et al. (2017), Kerai and Saleh (2017) \\
\hline New customer rates & Danesh Asgari et al. (2017), Lee et al. (2017) \\
\hline Response time to customer request & Cooper et al. (2017) \\
\hline Cost of R\&D & $\begin{array}{l}\text { Akkermans and Van Oorschot (2018), Malagueño et al. } \\
\text { (2018) }\end{array}$ \\
\hline Number of improved process & Akkermans and Van Oorschot (2018), Mehralian et al. (2017) \\
\hline Introduction of new product & Dinçer et al. (2017), Sainaghi et al. (2018) \\
\hline Staff satisfaction & Akkermans and Van Oorschot (2018), Kerai and Saleh (2017) \\
\hline Motivation index & Akkermans and Van Oorschot (2018) \\
\hline Productivity of staff & Bento et al. (2017) \\
\hline Staff Training Index & Akkermans and Van Oorschot (2018), Kerai and Saleh (2017) \\
\hline & \\
\hline
\end{tabular}




\section{Hybrid approach}

\subsection{Step-wise Weight Assessment Ratio Analysis (SWARA)}

The SWARA method is a popular tool for calculating weights related to performance measurement and the resulting importance levels.

Step-wise Weight Assessment Ratio Analysis (SWARA) (Keršuliene et al., 2010) is one of the MCDM methods which are based on a rational dispute resolution method (Keršuliene \& Turskis, 2011). In this model, experts have key roles. First, they express their preferences. Then, based on the average expert's judgements, the comparative importance of each aspect is calculated and the results are sorted in descending order. The weight of each criterion is calculated based upon the relative importance of the next more important criterion.

The steps of the SWARA method are as follows:

Step 1. First of all, all criteria are sorted from top to down by estimation of significance.

Step 2. Consider second criterion, experts specify the relative importance of criterion $j$ compared to the previous $(j-1)$ criterion. The ratio of this comparison is called comparative importance average of value or $S_{j}$.

Step 3. The coefficients $K_{j}$ are obtained by following equation:

$$
K_{j}= \begin{cases}1 & j=1, \\ S_{j}+1 & j>1 .\end{cases}
$$

Step 4. The recalculated weights denoted as $q_{j}$ are computed as follows:

$$
q_{j}=\left\{\begin{array}{cc}
1 & j=1, \\
\frac{K_{j-1}}{K_{j}} & j>1 .
\end{array}\right.
$$
Step 5 . The weights of criteria are identified by $W_{j}=\frac{q_{j}}{\sum_{k=1}^{n} q_{k}}$, where $W_{j}$ is the weight
of criterion $j$.

\subsection{Weighted Aggregated Sum Product Assessment (WASPAS)}

This method was introduced by Zavadskas et al. (2012). In this method the aggregated Weights Sum Model (WSM) and the Weighted Product Model (WPM) are used for better accuracy in decision making. The following steps illustrate the WASPAS method.

Step 1. Decision matrix: In the first step a decision matrix will be created.

$$
x=\left[\begin{array}{ccc}
x_{11} & \cdots & x_{1 n} \\
\vdots & \ddots & \vdots \\
x_{m 1} & \cdots & x_{m n}
\end{array}\right] .
$$

In this matrix, $m$ is the number of alternatives and $n$ is the number of criteria. $x_{i j}$ is an indicator of the performance of alternative $i$ regarding criterion $j$.

Step 2. Normalized data: The data will be normalized based on the following formulas. 
For benefit criteria (to be maximized)

For cost criteria (to be minimized)

$$
\bar{x}_{i j}=\frac{x_{i j}}{\max _{i} x_{i j}} .
$$

$$
\bar{x}_{i j}=\frac{\min _{i} x_{i j}}{x_{i j}} .
$$

It is assumed that the $x_{i j}$ values are positive to avoid interpretation problems or division by zero. The normalized values of $x_{i j}$ are shown as $\bar{x}_{i j}$.

Step 3. Calculation of the total relative importance of an alternative: In the WASPA method, a joint optimality criterion based on two subcriteria is used. The first subcriterion for optimality can be interpreted as weighted success and it is similar to the one used in the WSM (Weights Sum Model) method. This method is among the popular MCDM methods for evaluating a finite set of alternatives. Based on the WSM method the total relative importance of alternative $i$ is calculated as follows:

$$
Q_{i}^{(1)}=\sum_{j=1}^{n} \bar{x}_{i j} w_{j} .
$$

In this formula, the $w_{j}$ values are the weights of the $j$ th criterion. For the other subcriterion, the computing formula for the total relative importance of an alternative is as follows:

$$
Q_{i}^{(2)}=\prod_{j=1}^{n}\left(\bar{x}_{i j}\right)^{w_{j}}
$$

Step 4. Total relative importance of an alternative: Based on the combination of the two above criteria an overall criterion is calculated as follows:

$$
Q_{i}=0.5 Q_{i}^{(1)}+0.5 Q_{i}^{(2)}=0.5 \sum_{j=1}^{n} \bar{x}_{i j} w_{j}+0.5 \prod_{j=1}^{n}\left(\bar{x}_{i j}\right)^{w_{j}} .
$$

Zavadskas et al. (2013a, 2013b) suggested the following formula to increase accuracy and effectiveness of decision-making processes.

$$
Q_{i}=\lambda Q_{i}^{(1)}+(1-\lambda) Q_{(i)}^{2}=\lambda \sum_{j=1}^{n} \bar{x}_{i j} w_{j}+(1-\lambda) \prod_{j=1}^{n}\left(\bar{x}_{i j}\right)^{w_{j}}, \quad \lambda=0,0.1,0.2, \ldots, 1 .
$$

The ranking of alternatives is based on the $Q$ values and the best alternative is the one which has the highest $Q$ value (Šaparauskas et al., 2011). In the above formula, if $\lambda=0$ the WASPA method changes to the WPM (Weighted Product Model) method and in case of $\lambda=1$ the method corresponds to the WSM method

\section{Step 5. Calculation of optimal values for $\lambda$}

In Zavadskas et al. (2012) it is suggested to calculate values for $\lambda$ which lead to a maximal accuracy of estimation of the $Q$ values. Assuming that errors in determining the initial criteria values are stochastic, the variances of the two criteria $Q_{i}^{(1)}$ and $Q_{i}^{(2)}$ are considered as accuracy indicators and can be calculated as follows:

$$
\sigma^{2}\left(Q_{i}^{(1)}\right)=\sum_{j=1}^{n} w_{j}^{2} \sigma^{2}\left(\bar{x}_{i j}\right) ;
$$




$$
\sigma^{2}\left(Q_{i}{ }^{(2)}\right)=\sum_{j=1}^{n}\left[\frac{\prod_{j=1}^{n}\left(\bar{x}_{i j}\right)^{w_{j}} \times w_{j}}{\left(\bar{x}_{i j}\right)^{w_{j}}\left(\bar{x}_{i j}\right)^{\left(1-w_{j}\right)}}\right]^{2} \sigma^{2}\left(\bar{x}_{i j}\right) .
$$

The variance of the total relative importance of an alternative can then be calculated as

$$
\sigma^{2}\left(Q_{i}\right)=\lambda^{2} \sigma^{2}\left(Q_{i}^{(1)}\right)+(1-\lambda)^{2} \sigma^{2}\left(Q_{i}^{(2)}\right)
$$

Optimal values of $\lambda$ of an alternative can then be calculated (assuming that the derivative of the above function should be 0 ) as follows:

$$
\lambda=\frac{\sigma^{2}\left(Q_{i}^{(2)}\right)}{\sigma^{2}\left(Q_{i}^{(1)}\right)+\sigma^{2}\left(Q_{i}^{(2)}\right)} .
$$

The estimates of variances of normalized initial criteria values can be calculated as follows

$$
\sigma^{2}\left(\bar{x}_{i j}\right)=\left(\bar{x}_{\frac{i j}{t} k}\right)^{2} .
$$

Here, it is assumed that these values are normally distributed and that the uncertainty can be expressed by a exponential coefficient $k=0.10$ of the criteria values and a further multiplier $t=2.0$ depending on the distribution law of errors. The variance of the (standardized) initial criteria values can then be expressed as

$$
\sigma^{2}\left(\bar{x}_{i j}\right)=\left(0.05 \bar{x}_{i j}\right)^{2}
$$

for a credibility level $q=0.05$.

\subsection{Reasons for choosing WASPAS and SWARA}

Based on various research, Zavadskas et al. (2012) believe that the WASPAS technique is a better technique than the Weighted Product Model (WPM) and the Weighted Sum Model (WSM). In addition, among MCDM techniques usually one must select either an additive aggregation of criteria values (e.g. a multi-attribute utility function) or a multiplicative form of aggregation. Instead, the WASPAS method allows to select both types of MCDM aggregation techniques. Of course, there are various more complex methods in the field of MCDM which make smaller assumptions concerning the aggregation possibilities of criteria such as the family of outranking methods. However, WASPAS is still a rather uncomplicated and easy-to-use method which makes it attractive in practical settings.

The SWARA method for determining weights is flexible and works economically regarding required information input (such as comparisons) (Mardani et al., 2017). In particular, SWARA, works with a smaller amount of information to be assessed for determining weights ( $n-1$ judgements) compared to some other MCDM approaches, especially 
those which rely on pairwise comparisons $\left(1 / 2\left(n^{2}-n\right)\right.$ judgements) which is especially important for a larger number of criteria and when dealing with experts with a small amount of available time (e.g. managers). In addition, the method is not oversimplicstic as it does not require to determine weights directly which is know to be cumbersome when dealing with decision makers.

\section{Research methodology}

\subsection{Research methodology steps}

The steps of this research are the following:

Step I: In this step, PIs of banks are extracted from strategic planning based on BSC.

Step II: Next, weights for each PI are to be determined based on the SWARA method.

Step III: Define sampling of this research by Cochran's formula (see below).

Step IV: Designing a questionnaire based on PIs, banks and the WASPAS method.

Step V: Data gathering from questionnaires.

Step VI: Data analysis by the WASPAS software.

Step VII: Ranking banks based on PIs and the WASPAS method.

In the subsequent subsection the main steps are illustrated.

\subsection{Identification of PIs}

As mentioned before, BSC is a tool to translate strategy into a common language that everybody can understand. In this paper, the performance measurement of BSC is based on the following aspects:

- Financial perspective: total assets, income, total cost, debt, ROI, net profit.

- Customer perspective: customer satisfaction, market share, number of customers, new customer rates, response time to customer requests.

- Internal processes perspective: cost of R\&D, number of improved processes, introduction of new services.

- Learning and growth perspective: staff satisfaction, motivation index, productivity of employees, staff training index.

Although it is possible to add further perspectives to BSC models, the standard perspective appeared to be sufficient for the considered purposes. For instance, modern aspects in banking services and performance, such as innovations and IT support can be found among the existing perspectives as they have impact, e.g., on customer satisfaction, the improvement of internal services, or the productivity of employees. In addition, aspepts such as those relating to technology and innovation did not appear to be most relevant as the considered Colombian banks are, in general, lagging behind international top banks and FinTech newcomers. Therefore, additional perspectives were not considered.

Table 3 shows the PIs with their definitions and respective references. 
Table 3. PIs with their definitions and references

\begin{tabular}{|c|c|c|}
\hline PIs & Definition & Author/Authors \\
\hline Net profit & Net profit $=$ sales revenues - total costs & Child (1974), MacLeod et al. (2004) \\
\hline ROI & $\begin{array}{l}\text { Return on investment = net income / } \\
\text { investment }\end{array}$ & $\begin{array}{l}\text { Chen et al. (2011), Karbassi Yazdi and } \\
\text { Abdi (2017) }\end{array}$ \\
\hline Debt & $\begin{array}{l}\text { Debt reveals to money, that is owed } \\
\text { to someone else, or the state of owing } \\
\text { something }\end{array}$ & $\begin{array}{l}\text { Faraglia et al. (2008), Feng and Wang } \\
(2000)\end{array}$ \\
\hline Total cost & $\begin{array}{l}\text { It refers to both fixed costs and variable } \\
\text { costs }\end{array}$ & $\begin{array}{l}\text { Gannon et al. (2017), Yazdi et al. } \\
\text { (2018) }\end{array}$ \\
\hline Income & $\begin{array}{l}\text { Money that is earned from doing work } \\
\text { or received from investments }\end{array}$ & $\begin{array}{l}\text { Kumar and Vincent (2011), Yang and } \\
\text { Liu (2012) }\end{array}$ \\
\hline Total assets & $\begin{array}{l}\text { The summation of assets owned by a } \\
\text { company or person }\end{array}$ & Chen et al. (2013), Yazdi et al. (2018) \\
\hline $\begin{array}{l}\text { Customer } \\
\text { satisfaction }\end{array}$ & $\begin{array}{l}\text { The degree (expressed in percent) } \\
\text { of customers being satisfied by a } \\
\text { company's services or goods }\end{array}$ & $\begin{array}{l}\text { Chernikov et al. (2015), Saeidi et al. } \\
\text { (2015) }\end{array}$ \\
\hline Share market & $\begin{array}{l}\text { The percentage of the relevant market } \\
\text { served by the company }\end{array}$ & Kaya (2018), Tayeh et al. (2015) \\
\hline $\begin{array}{l}\text { Number of } \\
\text { customers }\end{array}$ & $\begin{array}{l}\text { The number of customers served by the } \\
\text { company }\end{array}$ & Azadeh et al. (2015), Tan et al. (2015) \\
\hline $\begin{array}{l}\text { New customer } \\
\text { rates }\end{array}$ & $\begin{array}{l}\text { A measure (rate) showing the success } \\
\text { to attract new customers }\end{array}$ & Fornell et al. (2016) \\
\hline $\begin{array}{l}\text { Response time to } \\
\text { customer request }\end{array}$ & $\begin{array}{l}\text { This refers to the time span from a } \\
\text { customer order to the fulfillment of the } \\
\text { request }\end{array}$ & $\begin{array}{l}\text { Diamantini et al. (2016), Hachicha } \\
\text { et al. (2016) }\end{array}$ \\
\hline Cost of R\&D & $\begin{array}{l}\text { The percentage of a company's budget } \\
\text { allocated to research and development } \\
(\mathrm{R} \& \mathrm{D})\end{array}$ & $\begin{array}{l}\text { Babkin et al. (2015), Lazzarotti et al. } \\
\text { (2011) }\end{array}$ \\
\hline $\begin{array}{l}\text { Number of } \\
\text { improved } \\
\text { processes }\end{array}$ & $\begin{array}{l}\text { The number of processes considered for } \\
\text { improvement }\end{array}$ & Podgórski (2015) \\
\hline $\begin{array}{l}\text { Introduction of } \\
\text { new products }\end{array}$ & $\begin{array}{l}\text { The number of new products } \\
\text { introduced to the market per year }\end{array}$ & $\begin{array}{l}\text { Franklin-Johnson et al., (2016), } \\
\text { Gërguri-Rashiti et al. (2017), Singh } \\
\text { et al. (2016) }\end{array}$ \\
\hline Staff satisfaction & $\begin{array}{l}\text { Indicator showing the satisfaction of a } \\
\text { company's staff }\end{array}$ & $\begin{array}{l}\text { Kanyurhi and Bugandwa Mungu } \\
\text { Akonkwa (2016), Patiar and Wang } \\
\text { (2016) }\end{array}$ \\
\hline Motivation index & $\begin{array}{l}\text { Indcator which shows the motivation of } \\
\text { a company's staff }\end{array}$ & Vilanova et al. (2015) \\
\hline $\begin{array}{l}\text { Productivity of } \\
\text { staff }\end{array}$ & $\begin{array}{l}\text { Indicator of the productive staff of a } \\
\text { company in percent }\end{array}$ & Amelec and Carmen (2015a, 2015b) \\
\hline
\end{tabular}

\subsection{Weighting the PIs}

These PIs are ranked by the SWARA method. In this step, weights are to be determined for the performance indicators. First DMs were asked to specify their preferences for the indicators. These DMs were eleven top managers in the areas of banking and economics in Colom- 
bia. A group decision-making approach was used for both SWARA and WASPAS for ranking these indicators. Table 4 shows the weights and ranking of PIs by the SWARA method.

Table 4 . Weights obtained by the SWARA method

\begin{tabular}{|l|c|c|c|c|}
\hline \multicolumn{1}{|c|}{ PIs } & $\begin{array}{c}\text { Comparative } \\
\text { importance of } \\
\text { average value } \boldsymbol{S}_{\boldsymbol{j}}\end{array}$ & $\begin{array}{c}\text { Coefficient } \\
\boldsymbol{K}_{\boldsymbol{j}}=\boldsymbol{S}_{\boldsymbol{j}}+1\end{array}$ & $\begin{array}{c}\text { Recalculated } \\
\text { weight } \\
\boldsymbol{W}_{\boldsymbol{j}}=\frac{\boldsymbol{x}_{\boldsymbol{j}-1}}{\boldsymbol{K}_{\boldsymbol{j}}}\end{array}$ & $\begin{array}{c}\text { Weight } \\
\boldsymbol{q}_{\boldsymbol{j}}\end{array}$ \\
\hline Net profit & - & 1 & 1 & 0.273 \\
\hline ROI & 0.245 & 1.245 & 0.803 & 0.219 \\
\hline Debt $\boldsymbol{w}_{\boldsymbol{j}}$ & 1.356 & 0.592 & 0.161 \\
\hline Total cost & 0.356 & 1.412 & 0.420 & 0.114 \\
\hline Income & 0.412 & 1.562 & 0.269 & 0.073 \\
\hline Total assets & 0.562 & 1.476 & 0.182 & 0.050 \\
\hline Customer satisfaction & 0.476 & 1.465 & 0.124 & 0.034 \\
\hline Share market & 0.465 & 1.541 & 0.081 & 0.022 \\
\hline Number of customers & 0.541 & 1.489 & 0.054 & 0.015 \\
\hline New customer rates & 0.489 & 1.359 & 0.040 & 0.011 \\
\hline Response time to customer request & 0.359 & 1.403 & 0.028 & 0.008 \\
\hline Cost of R\&D & 0.403 & 1.256 & 0.023 & 0.006 \\
\hline Number of improved process & 0.256 & 1.305 & 0.017 & 0.005 \\
\hline Introduction of new product & 0.305 & 1.289 & 0.013 & 0.004 \\
\hline Staff satisfaction & 0.289 & 1.415 & 0.009 & 0.003 \\
\hline Motivation index & 0.415 & 1.516 & 0.006 & 0.002 \\
\hline Productivity of staff & 0.516 & 1.478 & 0.004 & 0.001 \\
\hline Staff Training Index & 0.478 & 1.459 & 0.003 & 0.001 \\
\hline
\end{tabular}

\subsection{Data sampling}

For data sampling, Cochran's sample size formula for the infinite population is used. The formula is as follows:

$$
n=\frac{z^{2} \times p \times(1-p)}{d^{2}},
$$

where $z$-confidence level, $p$ - the percentage of people in the population who have the attribute, $(1-p)$ - the percentage of people in the population who do not have the attribute, and $d$ - the allowed error.

In this study, $z$ corresponds to $95 \%$ or $1.96, p$ and (1-p) are equal to 0.5 and $d$ is equal to 0.1 . By putting these numbers into the formula the questionnaire needs to be distributed to 96 persons. As interviewees for this questionnaire Colombian individuals were considered that have an account at one of these banks. It was necessary to send the questionnaire to 107 randomly selected customers (because of nonresponding customers) in order to get the desired 96 responses. 


\begin{tabular}{|c|c|c|c|c|c|c|}
\hline 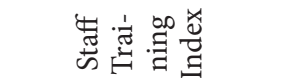 & $\vec{n}$ & $\begin{array}{l}\text { in } \\
\text { in }\end{array}$ & 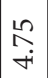 & 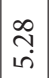 & io & बे \\
\hline 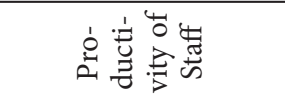 & 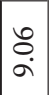 & $\frac{0}{m}$ & $\stackrel{\text { mे }}{+}$ & $\begin{array}{l}0 \\
i n \\
\infty\end{array}$ & $\vec{m}$ & $\begin{array}{l}\infty \\
\stackrel{\infty}{\circ}\end{array}$ \\
\hline 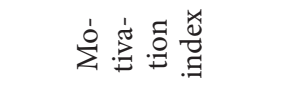 & $\begin{array}{l}\infty \\
\stackrel{\infty}{i n} \\
i n\end{array}$ & $\begin{array}{l}\hat{a} \\
\infty\end{array}$ & $\stackrel{+}{m}$ & 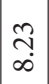 & F̆ & $\underset{\dot{m}}{\stackrel{+}{m}}$ \\
\hline 出 总总芯 & $\begin{array}{l}\stackrel{2}{n} \\
m \\
m\end{array}$ & $\begin{array}{l}0 \\
n \\
n \\
n\end{array}$ & $\begin{array}{l}\frac{1}{N} \\
N\end{array}$ & $\begin{array}{l}\infty \\
0 \\
\infty\end{array}$ & $\begin{array}{l}\hat{\sigma} \\
\text { in }\end{array}$ & 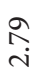 \\
\hline 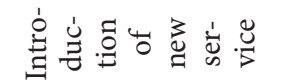 & $\stackrel{\infty}{\stackrel{\infty}{-}}$ & $\begin{array}{l}n \\
i \\
i\end{array}$ & $\begin{array}{l}\infty \\
\infty \\
\infty \\
\infty\end{array}$ & $\begin{array}{c}n \\
m \\
i n\end{array}$ & ț & fे \\
\hline 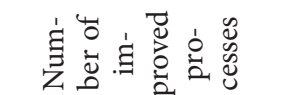 & $\begin{array}{l}\infty \\
\underset{\infty}{\rightarrow}\end{array}$ & $\begin{array}{l}\infty \\
\infty \\
+ \\
+ \\
+\end{array}$ & 苞 & $\underset{\infty}{m}$ & 눙 & 范 \\
\hline 苍 & 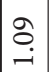 & ח̂n & $\begin{array}{l}\infty \\
m \\
n \\
n\end{array}$ & $\mid \begin{array}{l}0 \\
1 \\
10\end{array}$ & $\begin{array}{l}2 \\
i \\
i n\end{array}$ & $\begin{array}{l}0 \\
\infty \\
\infty\end{array}$ \\
\hline 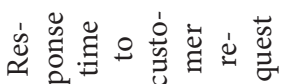 & $\stackrel{\underset{\sim}{\sim}}{\rightarrow}$ & $\begin{array}{l}\infty \\
\infty \\
\dot{n}\end{array}$ & $\begin{array}{l}0 \\
6 \\
i\end{array}$ & $\stackrel{\hat{\sigma}}{-}$ & $\stackrel{\infty}{a}$ & $\stackrel{\text { iे }}{\text { in }}$ \\
\hline 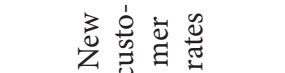 & $\begin{array}{l}\infty \\
\infty \\
N\end{array}$ & $\begin{array}{l}2 \\
\dot{m}\end{array}$ & $\begin{array}{l}\infty \\
0 \\
i\end{array}$ & $\begin{array}{l}\stackrel{2}{\infty} \\
+ \\
+\end{array}$ & $\underset{\infty}{\infty}$ & $\stackrel{\infty}{\sim}$ \\
\hline 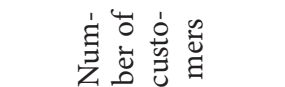 & $\begin{array}{c}\tilde{n} \\
\stackrel{n}{n}\end{array}$ & 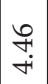 & $\stackrel{n}{n}$ & $\underset{\infty}{2}$ & $\begin{array}{l}\infty \\
\infty \\
\dot{n}\end{array}$ & $\begin{array}{l}0 \\
\infty \\
\infty\end{array}$ \\
\hline 莺芯芯 & $\cong$ & 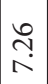 & $\begin{array}{l}m \\
i n \\
i n\end{array}$ & $\begin{array}{l}\infty \\
\infty \\
\dot{n}\end{array}$ & $\begin{array}{l}2 \\
\infty \\
0 \\
0\end{array}$ & $\begin{array}{l}\text { mे } \\
\text { in }\end{array}$ \\
\hline 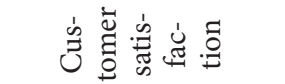 & $\hat{\kappa}$ & $\stackrel{m}{\hat{\sigma}}$ & 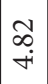 & $\begin{array}{c}\infty \\
+ \\
0 \\
\vdots\end{array}$ & $\stackrel{m}{\stackrel{n}{r}}$ & $\widehat{\overbrace{}}$ \\
\hline 壳莒 & $\stackrel{\overbrace{}}{\rightarrow}$ & \begin{tabular}{|l}
4 \\
in \\
in
\end{tabular} & $\stackrel{\hat{n}}{i}$ & $\begin{array}{l}0 \\
\infty \\
\infty\end{array}$ & nn & ֻ̊ \\
\hline Oิ & के & $\stackrel{m}{\hat{a}}$ & $\stackrel{n}{n}$ & $\begin{array}{l}10 \\
\infty \\
\infty\end{array}$ & å & กֶ? \\
\hline$\frac{\overrightarrow{0}}{0}$ & 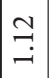 & $\stackrel{\overbrace{}}{\stackrel{\sim}{\sim}}$ & $\begin{array}{l}\infty \\
\infty \\
\infty\end{array}$ & 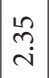 & in & $\begin{array}{l}\vec{b} \\
\text { in }\end{array}$ \\
\hline 炡苟 & $\begin{array}{l}\infty \\
0 \\
0\end{array}$ & ô & 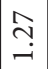 & $\underset{+}{\stackrel{+}{+}}$ & 总 & $\stackrel{\stackrel{n}{N}}{n}$ \\
\hline 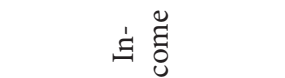 & $\begin{array}{l}\infty \\
ٌ \\
\emptyset\end{array}$ & $\stackrel{\sim}{ユ}$ & 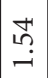 & $\hat{\circ}$ & $\stackrel{+}{m}$ & $\stackrel{?}{*}$ \\
\hline 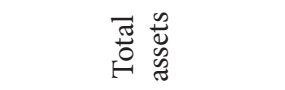 & $\dddot{m}$ & in & $\ddot{m}$ & $\stackrel{m}{m}$ & $\stackrel{2}{a}$ & $\stackrel{i}{i}$ \\
\hline 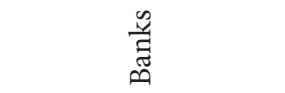 & $\vec{\infty}$ & $\tilde{\infty}$ & $\tilde{\varphi}$ & $\ddot{n}$ & $\stackrel{10}{n}$ & ஜ \\
\hline
\end{tabular}

\begin{tabular}{|c|c|c|c|c|c|c|}
\hline 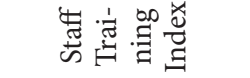 & $\begin{array}{l}\mathbb{H} \\
\stackrel{0}{0}\end{array}$ & 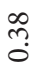 & $\stackrel{m}{0}$ & $\hat{n}$ & $\stackrel{\circ}{0}$ & ঙุ. \\
\hline 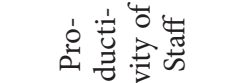 & 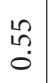 & $\stackrel{9}{0}$ & ஸे & $\begin{array}{l}\tilde{n} \\
0 \\
0\end{array}$ & $\stackrel{\sharp}{\stackrel{1}{0}}$ & $\begin{array}{l}\text { in } \\
\text { in }\end{array}$ \\
\hline 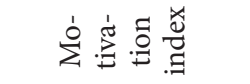 & ڤ్ & $\begin{array}{l}\infty \\
\stackrel{1}{n} \\
0\end{array}$ & $\begin{array}{l}0 \\
\dot{0}\end{array}$ & $\begin{array}{l}n \\
\hat{n} \\
0\end{array}$ & $\stackrel{1}{\ddagger}$ & 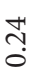 \\
\hline 恚总总灾 & $\stackrel{\vec{\sigma}}{\tilde{\sigma}}$ & $\stackrel{\infty}{\sharp ! ~}$ & $\vec{n}$ & $\begin{array}{l}n \\
\text { n? } \\
0\end{array}$ & ले & $\stackrel{\infty}{\stackrel{0}{0}}$ \\
\hline 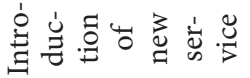 & $\begin{array}{l}\stackrel{0}{0} \\
0\end{array}$ & $\stackrel{\overbrace{}}{0}$ & $\hat{\widehat{\sigma}}$ & $\underset{H}{H}$ & ले & సે \\
\hline 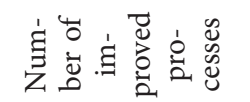 & $\stackrel{\text { f̆ }}{\circ}$ & $\stackrel{\sim}{\stackrel{n}{0}}$ & 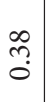 & $\begin{array}{l}\infty \\
\stackrel{+}{0} \\
0\end{array}$ & กี? & $\begin{array}{l}\text { İ } \\
\text { on }\end{array}$ \\
\hline 苑山旅 & $\stackrel{\infty}{0}$ & $\stackrel{\infty}{\rightarrow}$ & กี & $\begin{array}{l}F \\
0\end{array}$ & $\underset{0}{F}$ & : \\
\hline 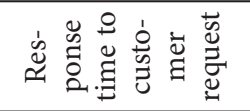 & $\stackrel{1}{\circ}$ & 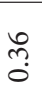 & 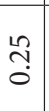 & $\begin{array}{l}0 \\
\stackrel{0}{0}\end{array}$ & $\begin{array}{l}\infty \\
\infty \\
0\end{array}$ & $\stackrel{9}{\circ}$ \\
\hline 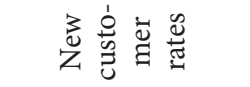 & ज़? & $\stackrel{\sim}{\tilde{O}}$ & $\stackrel{m}{0}$ & $\stackrel{\tilde{n}}{0}$ & กี & $\begin{array}{l}\text { th } \\
\text { th }\end{array}$ \\
\hline 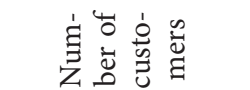 & $\stackrel{+}{\sim}$ & $\ddot{0}$ & $\overrightarrow{0}$ & in & ㅁ․ & : \\
\hline 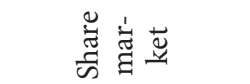 & 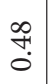 & $\stackrel{\infty}{\stackrel{\infty}{0}}$ & 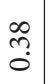 & $\begin{array}{l}\mathscr{l} \\
\text { గె }\end{array}$ & $\stackrel{\leftrightarrow}{\circ}$ & $\begin{array}{l}\stackrel{0}{0} \\
\text { n. }\end{array}$ \\
\hline 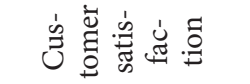 & $\begin{array}{l}\stackrel{0}{0} \\
\stackrel{0}{0}\end{array}$ & $\stackrel{0}{\circ}$ & $\begin{array}{c}m \\
\tilde{0}\end{array}$ & \begin{tabular}{l}
\multirow{H}{*}{} \\
0
\end{tabular} & $\stackrel{2}{\circ}$ & $\begin{array}{l}0 \\
0 \\
0\end{array}$ \\
\hline 芯䓂 & $\begin{array}{l}8 \\
0 \\
0\end{array}$ & 용 & $\begin{array}{c}0 \\
\stackrel{0}{0}\end{array}$ & $\begin{array}{c}\infty \\
\stackrel{\infty}{?} \\
0\end{array}$ & $\stackrel{\text { N̦ }}{0}$ & $\begin{array}{l}\text { ț } \\
0\end{array}$ \\
\hline 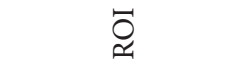 & กี? & in & $\stackrel{m}{0}$ & $\begin{array}{l}\infty \\
\stackrel{+}{0} \\
0\end{array}$ & $\stackrel{0}{-1}$ & $\underset{0}{F}$ \\
\hline 苛 & $\begin{array}{l}\infty \\
\stackrel{\infty}{0} \\
0\end{array}$ & $\begin{array}{l}\widetilde{V} \\
0\end{array}$ & $\begin{array}{l}\infty \\
\stackrel{0}{0} \\
0\end{array}$ & $\tilde{n}$ & $\frac{\overrightarrow{1}}{0}$ & $\stackrel{+}{-}$ \\
\hline $\begin{array}{ll}\vec{\pi} & \overrightarrow{0} \\
0 & 0 \\
0 & 0\end{array}$ & $\stackrel{\vartheta}{\overrightarrow{0}}$ & $\stackrel{m}{0}$ & $\begin{array}{l}\stackrel{2}{0} \\
\vdots\end{array}$ & 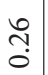 & $\vec{\tau}$ & $\begin{array}{l}0 \\
0 \\
0\end{array}$ \\
\hline 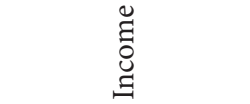 & $\stackrel{0}{\circ}$ & Oे. & \begin{tabular}{l}
0 \\
\hdashline \\
0
\end{tabular} & $\begin{array}{l}\stackrel{8}{0} \\
\dot{0}\end{array}$ & $\stackrel{\text { oे }}{0}$ & $\begin{array}{l}\text { గ్ర } \\
0\end{array}$ \\
\hline 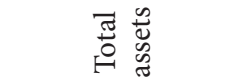 & $\begin{array}{l}m \\
\text { ñ? } \\
0\end{array}$ & $\stackrel{m}{0}$ & $\begin{array}{l}F \\
0\end{array}$ & \begin{tabular}{l}
$\infty$ \\
\multirow{2}{0}{}
\end{tabular} & مै? & $\frac{m}{0}$ \\
\hline$\frac{\mathscr{y}}{\tilde{E}}$ & $\vec{\emptyset}$ & $\tilde{\infty}$ & $\tilde{\emptyset}$ & $\vec{D}$ & $\stackrel{\varphi}{\oplus}$ & ஜి \\
\hline
\end{tabular}




\begin{tabular}{|c|c|c|c|c|c|c|}
\hline 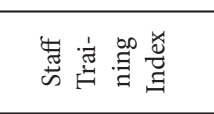 & $\begin{array}{l}m \\
\stackrel{0}{0} \\
\stackrel{0}{0} \\
0\end{array}$ & 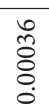 & $\begin{array}{l}\widehat{\widehat{o}} \\
\text { ठ̣ } \\
\dot{0}\end{array}$ & 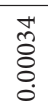 & $\begin{array}{l}1 \\
\text { Oे } \\
\text { ठ̊. } \\
0\end{array}$ & $\begin{array}{l}\text { ma } \\
\text { m. } \\
\vdots \\
0 \\
0\end{array}$ \\
\hline 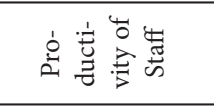 & 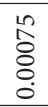 & $\begin{array}{l}o \\
\vdots \\
\vdots \\
0\end{array}$ & 我 & $\begin{array}{l}\hat{0} \\
\vdots \\
\vdots \\
0\end{array}$ & $\begin{array}{l}\text { 눙 } \\
\vdots \\
\vdots \\
0\end{array}$ & $\begin{array}{l}0 \\
\hat{0} \\
\vdots \\
0 \\
0\end{array}$ \\
\hline 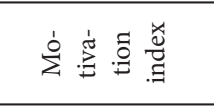 & 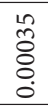 & $\begin{array}{l}\stackrel{1}{0} \\
\stackrel{0}{0} \\
\vdots \\
0\end{array}$ & ڤิ & 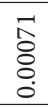 & 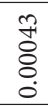 & $\begin{array}{l}\text { ñ } \\
\vdots \\
\vdots \\
0 \\
0\end{array}$ \\
\hline 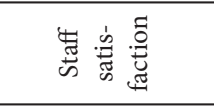 & ت্ & $\begin{array}{l}\infty \\
\leftrightarrow \\
0 \\
0 \\
0\end{array}$ & 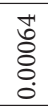 & \begin{tabular}{l}
0 \\
\multirow{0}{0}{} \\
0 \\
0
\end{tabular} & $\begin{array}{l}\infty \\
\dddot{0} \\
\vdots \\
0\end{array}$ & $\begin{array}{l}\infty \\
\vdots \\
\vdots \\
0 \\
0\end{array}$ \\
\hline 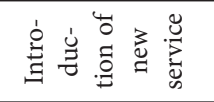 & 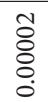 & $\begin{array}{l}m \\
\stackrel{m}{0} \\
\stackrel{0}{0} \\
0\end{array}$ & 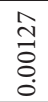 & 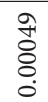 & 商 & $\begin{array}{l}\widetilde{\widetilde{\delta}} \\
\vdots \\
\vdots \\
0\end{array}$ \\
\hline 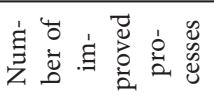 & $\begin{array}{l}10 \\
\text { Lิ } \\
0 \\
0 \\
0\end{array}$ & $\begin{array}{l}0 \\
\stackrel{0}{0} \\
8 \\
0 \\
0\end{array}$ & 命 & $\begin{array}{l}\infty \\
0 \\
\vdots \\
0 \\
0 \\
0\end{array}$ & $\begin{array}{l}\infty \\
0 \\
8 \\
0 \\
0 \\
0\end{array}$ & $\begin{array}{l}1 \\
\overline{8} \\
\vdots \\
0 \\
0\end{array}$ \\
\hline 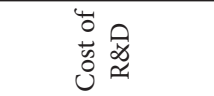 & ڤৃ & $\begin{array}{l}\infty \\
\stackrel{0}{0} \\
\vdots \\
0\end{array}$ & 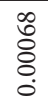 & 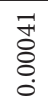 & F & 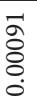 \\
\hline 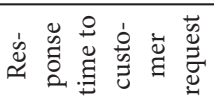 & $\begin{array}{l}m \\
\vdots \\
\vdots \\
0\end{array}$ & $\begin{array}{l}m \\
\stackrel{0}{0} \\
\vdots \\
0\end{array}$ & $\begin{array}{l}\text { Ln } \\
\\
\vdots \\
0\end{array}$ & $\begin{array}{l}0 \\
\vdots \\
\vdots \\
0\end{array}$ & $\begin{array}{l}m \\
\infty \\
\vdots \\
0 \\
0\end{array}$ & $\begin{array}{l}0 \\
\stackrel{0}{8} \\
8 \\
0\end{array}$ \\
\hline 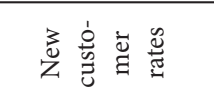 & $\begin{array}{l}10 \\
\vdots \\
0\end{array}$ & $\begin{array}{l}0 \\
0 \\
8 \\
8 \\
0\end{array}$ & 능 & 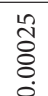 & 象 & 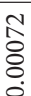 \\
\hline 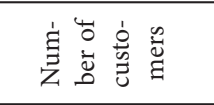 & $\begin{array}{l}\text { Ln } \\
\stackrel{0}{0} \\
\vdots \\
0\end{array}$ & 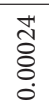 & $\begin{array}{l}\text { ôे } \\
\text { } \\
0 \\
0\end{array}$ & $\begin{array}{l}0 \\
\stackrel{0}{0} \\
8 \\
0 \\
0\end{array}$ & $\begin{array}{l}\text { 웅 } \\
8 \\
8 \\
0\end{array}$ & $\begin{array}{l}2 \\
\stackrel{0}{0} \\
\dot{8} \\
\dot{0}\end{array}$ \\
\hline 䒕离离 & $\begin{array}{l}\text { in } \\
\text { i⿱ } \\
0\end{array}$ & $\begin{array}{l}\infty \\
\text { L } \\
8 \\
0 \\
0\end{array}$ & $\begin{array}{l}0 \\
\text { ֻి } \\
8 \\
0\end{array}$ & $\begin{array}{l}0 \\
\vdots \\
8 \\
0 \\
0\end{array}$ & $\begin{array}{l}\text { กิ } \\
\text { ถุ } \\
0 \\
0\end{array}$ & 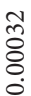 \\
\hline 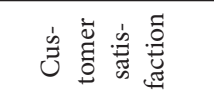 & $\begin{array}{l}\circ \\
\stackrel{1}{\circ} \\
\stackrel{\circ}{0}\end{array}$ & $\begin{array}{l}\text { ñ } \\
\stackrel{2}{8} \\
8 \\
0\end{array}$ & $\begin{array}{l}\hat{\widehat{o}} \\
\text { ठ̊. }\end{array}$ & 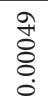 & $\begin{array}{l}0 \\
\dot{8} \\
\dot{8}\end{array}$ & $\begin{array}{l}\text { İ } \\
\vdots \\
\vdots \\
0\end{array}$ \\
\hline 芯葋 & 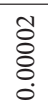 & $\begin{array}{l}\text { 우 } \\
\vdots \\
0 \\
0\end{array}$ & 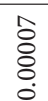 & $\begin{array}{l}\stackrel{1}{\infty} \\
\stackrel{0}{8} \\
\vdots \\
0\end{array}$ & 눙 & $\begin{array}{l}\text { ô } \\
\vdots \\
0 \\
0\end{array}$ \\
\hline م્વ & $\begin{array}{l}\infty \\
0 \\
\varnothing \\
8 \\
0\end{array}$ & $\begin{array}{l}\text { No } \\
8 \\
8 \\
0\end{array}$ & $\begin{array}{l}+1 \\
\vdots \\
8 \\
0 \\
0\end{array}$ & 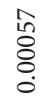 & $\begin{array}{l}\hat{8} \\
\dot{8} \\
0 \\
0\end{array}$ & ঙै \\
\hline$\frac{\overrightarrow{0}}{0}$ & $\begin{array}{l}0 \\
\stackrel{1}{1} \\
\stackrel{8}{0}\end{array}$ & $\begin{array}{l}\circ \\
8 \\
8 \\
0 \\
0\end{array}$ & 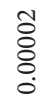 & 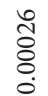 & 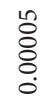 & 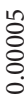 \\
\hline 琎 & 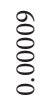 & $\begin{array}{l}\text { H' } \\
0 \\
8 \\
0\end{array}$ & 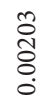 & $\begin{array}{l}1 \\
\stackrel{0}{\circ} \\
\stackrel{0}{0}\end{array}$ & $\begin{array}{l}ت \\
\overline{8} \\
\dot{0}\end{array}$ & ङั \\
\hline$\dot{\Xi}$ & 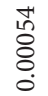 & $\begin{array}{l}\ddot{\circ} \\
\vdots \\
\dot{0}\end{array}$ & $\begin{array}{l}0 \\
\vdots \\
\vdots\end{array}$ & $\begin{array}{l}\ddot{\circ} \\
\dot{8} \\
\dot{0}\end{array}$ & 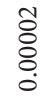 & ஓे \\
\hline 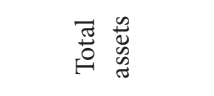 & 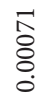 & 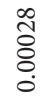 & $\begin{array}{l}\text { Iै } \\
\stackrel{0}{0} \\
0\end{array}$ & $\begin{array}{l}\stackrel{0}{\circ} \\
\vdots \\
0\end{array}$ & $\begin{array}{l}0 \\
0 \\
0 \\
0 \\
0\end{array}$ & $\begin{array}{l}\text { 녕 } \\
\vdots \\
0 \\
0\end{array}$ \\
\hline 营 & $\vec{\infty}$ & $\widetilde{\infty}$ & $\tilde{\infty}$ & $\ddot{D}$ & $\mathscr{n}$ & ஜ \\
\hline
\end{tabular}




\subsection{Data collection}

For data collection a questionnaire for the DMs was used. In this questionnaire, the DMs responses to questions regarding the performance of banks are based on PIs. In this study, six selected banks in Colombia were considered. These banks included all Colombian banks (six from seven banks) where access their data was possible. For confidentiality reasons, the names of the banks are not specified in the respective data and are indicated by B1, B2, B3, B4, B5, and B6. While five of these financial institutions are domestic banks, one is a branch of an international bank.

\section{Data analysis}

After distributing the questionnaires to the DMs, the resulting data are gathered and analyzed.

First, the average of evaluations from the responses is calculated. Table 5 shows the decision matrix data of the WASPAS method.

The normalized data are shown in Table 6.

The variance matrix as calculated by the WASPAS software for the individual criteria values is shown in Table 7.

The variance of data for the quality indicators $Q_{i}^{(1)}$ and $Q_{i}^{(2)}$ is presented in Table 8 .

Table 8. The variance data for the quality indicators $Q_{i}^{(1)}$ and $Q_{i}^{(2)}$

\begin{tabular}{|c|c|c|}
\hline Banks & $Q^{(1)}$ & $Q^{(2)}$ \\
\hline B1 & 0.000054 & 0.000067 \\
\hline B2 & 0.000018 & 0.000023 \\
\hline B3 & 0.00006 & 0.000025 \\
\hline B4 & 0.000035 & 0.000058 \\
\hline B5 & 0.000038 & 0.000023 \\
\hline B6 & 0.000033 & 0.000025 \\
\hline
\end{tabular}

Then $\lambda$ and $Q_{i}$ are calculated. The $Q_{i}$ values show the ranking of alternatives Final ranking of this research indicates in Table 9.

The resulting ranking of banks is $B 1>B 4>B 6>B 2>B 3>B 6$

Table 9. Ranking of banks

\begin{tabular}{|c|c|c|c|}
\hline Banks & $\lambda$ & $Q_{i}$ & Ranking \\
\hline B1 & 0.554 & 0.423 & 1 \\
\hline B2 & 0.568 & 0.271 & 4 \\
\hline B3 & 0.293 & 0.271 & 5 \\
\hline B4 & 0.622 & 0.384 & 6 \\
\hline B5 & 0.374 & 0.256 & 3 \\
\hline B6 & 0.433 & 0.273 & 2 \\
\hline
\end{tabular}




\section{Managerial implications}

The banking industry has usually a key role in the economy of a country. Banks provide many services for customers. Banks can be divided into domestic and international banks. Today, these banks compete with each other to attract customers. As a consequence, they provide the customers with new high quality services. This competition helps customers choose the banks with the best services, terms, and conditions. Colombian banks are not exceptional in this regard. After international banks arrived in Colombia, a new rivalry started in the banking industry. As the number of banks in Colombia is small, the competition is rather strong. Therefore, Colombians want to assess these banks and find out which has the best performance. To assess their performance, the BSC method is used. It is a powerful tool for the translation of strategies into action. Based on BSC, first performance indicators are extracted. Then weights are allocated to these PIs based on the SWARA method. The result of the SWARA method revealed that among these PIs the net profit indicator from the financial perspective had the highest priority and weight, whereas the staff training index from the learning and growth perspective had the lowest priority and weight among the PIs.

Based on the preferences specified by the DMs, six banks in Colombia, which included five local banks and one international bank, were assessed regarding their performance indicators. For evaluating these banks, 18 performance indicators in financial, customer, internal and learning and growth perspectives are considered. The banks are ranked based on the DMs preferences and, the performance indicators and the WASPAS method. As the WASPAS method is based on a decision matrix, specified weights are required. To obtain these weights, the SWARA method is used. The result shows that of the six banks the international bank has the highest performance from the DMs' viewpoints. This indicates that this bank provides suitable services on time and with a high quality. The next banks in the ranking are domestic banks. There is a significant difference between the score of the international bank and the domestic bank which ranks second. The score of the other banks did not differ much. To increase their performance, domestic banks need to benchmark with the international bank in terms of performance measurement criteria.

\section{Conclusions}

Based on a literature review, 18 performance indicators for banks were extracted which are relevant for strategic planning. These performance indicators were categorized into four categories of BSC, which are denoted as financial, customer, internal processes, learning and growth perspectives. Based on these perspectives, six performance indicators from the financial perspective, five performance indicators from the customer perspective, three performance indicators from the internal processes perspective, and finally, four performance indicators from the growth and learning perspectives were considered. This means that financial and customer perspectives and performance measurement had key roles for the assessment of these banks. Then, the performance indicators were ranked by using SWARA. Among these performance indicators the net profit had the highest priority and the staff 
training index had the lowest priority. As mentioned before, the ranking of banks were $B 1>B 4>B 6>B 2>B 3>B 6$ where the international bank (B1) had the highest performance and bank B6, which is a domestic bank, had the lowest performance.

During the study it turned out that both SWARA and WASPAS are rather easy to use and can be applied in a scenario involving experts (for some application domain) who are not familiar with these approaches. The approaches are easier to use (with respect to the elicited information and regarding their outcomes) than various other MCDM methods (such as some outranking approaches, for instance). On the oter hand, these approaches are not oversimplistic, e.g. regading the assessment of weights or with respect to the subsequent aggregation of criteria.

Regarding limitations of this study, it is well-known from other applications, that results of multicriteria problems may differ more or less as a result of different information used in different MCDM approaches and the way how the information is processed. For future research, therefore other methods can be used which are based on pairwise comparisons such as AHP, ANP, MACBETH, Rembrandt and so on for finding weights for evaluating a decision matrix for the considered application area. In addition, for ranking banks researchers can use other MCDM methods such as COPRAS, ARAS, TOPSIS, or VIKOR. It would be interesting to find out differences rearding the results obtained by different methods. In addition, the suggested methodology should be used for evaluating companies in other countries or from different industries.

\section{References}

Akkermans, H. A., \& van Oorschot, K. E. (2018). Relevance assumed: A case study of balanced scorecard development using system dynamics. In M. Kunc (Ed.), System dynamics (pp. 107-132). Springer. https://doi.org/10.1057/978-1-349-95257-1_4

Akkoç, S., \& Vatansever, K. (2013). Fuzzy performance evaluation with AHP and Topsis methods: evidence from Turkish banking sector after the global financial crisis. Eurasian Journal of Business and Economics, 6(11), 53-74.

Amelec, V., \& Carmen, V. (2015a). Relationship between variables of performance social and financial of microfinance institutions. Advanced Science Letters, 21(6), 1931-1934. https://doi.org/10.1166/asl.2015.6163

Amelec, V., \& Carmen, V. (2015b). Validation of a model for productivity evaluation for microfinance institutions. Advanced Science Letters, 21(5), 1610-1614. https://doi.org/10.1166/asl.2015.6117

Asli, M. N., Dalfard, V. M., \& Poursalik, K. (2013). A combination model using strategic alignment model and balanced scorecard and strategies' prioritisation based on TOPSIS technique. International Journal of Productivity and Quality Management, 12(3), 313-326. https://doi.org/10.1504/IJPQM.2013.056151

Asmild, M., Paradi, J. C., Aggarwall, V., \& Schaffnit, C. (2004). Combining DEA window analysis with the Malmquist index approach in a study of the Canadian banking industry. Journal of Productivity Analysis, 21(1), 67-89. https://doi.org/10.1023/B:PROD.0000012453.91326.ec

Azadeh, A., Haghighi, S. M., Zarrin, M., \& Khaefi, S. (2015). Performance evaluation of Iranian electricity distribution units by using stochastic data envelopment analysis. International Journal of Electrical Power \& Energy Systems, 73, 919-931. https://doi.org/10.1016/j.ijepes.2015.06.002 
Babkin, A. V., Lipatnikov, V. S., \& Muraveva, S. V. (2015). Assessing the impact of innovation strategies and R\&D costs on the performance of IT companies. Procedia - Social and Behavioral Sciences, 207, 749-758. https://doi.org/10.1016/j.sbspro.2015.10.153

Bazrkar, A., Iranzadeh, S., \& Feghhi Farahmand, N. (2017). Total quality model for aligning organization strategy, improving performance, and improving customer satisfaction by using an approach based on combination of balanced scorecard and lean six sigma. Cogent Business \& Management, 4(1), 1390818. https://doi.org/10.1080/23311975.2017.1390818

Beheshtinia, M. A., \& Omidi, S. (2017). A hybrid MCDM approach for performance evaluation in the banking industry. Kybernetes, 46(8), 1386-1407. https://doi.org/10.1108/K-03-2017-0105

Beheshtinia, M., \& Nemati-Abozar, V. (2017). A novel hybrid fuzzy multi-criteria decision-making model for supplier selection problem (A case study in advertising industry). Journal of Industrial and Systems Engineering, 9(4), 65-79.

Bennett, M., James, P., \& Klinkers, L. (2017). Key themes in environmental, social and sustainability performance evaluation and reporting. In Sustainable measures (pp. 29-74). Routledge. https://doi.org/10.4324/9781351283007-2

Bentes, A. V., Carneiro, J., da Silva, J. F., \& Kimura, H. (2012). Multidimensional assessment of organizational performance: Integrating BSC and AHP. Journal of Business Research, 65(12), 1790-1799. https://doi.org/10.1016/j.jbusres.2011.10.039

Bento, R. F., Mertins, L., \& White, L. F. (2017). Ideology and the balanced scorecard: An empirical exploration of the tension between shareholder value maximization and corporate social responsibility. Journal of Business Ethics, 142(4), 769-789. https://doi.org/10.1007/s10551-016-3053-6

Bhattacharya, A., Mohapatra, P., Kumar, V., Dey, P. K., Brady, M., Tiwari, M. K., \& Nudurupati, S. S. (2014). Green supply chain performance measurement using fuzzy ANP-based balanced scorecard: a collaborative decision-making approach. Production Planning \& Control, 25(8), 698-714. https://doi.org/10.1080/09537287.2013.798088

Chen, F.-H., Hsu, T.-S., \& Tzeng, G.-H. (2011). A balanced scorecard approach to establish a performance evaluation and relationship model for hot spring hotels based on a hybrid MCDM model combining DEMATEL and ANP. International Journal of Hospitality Management, 30(4), 908-932. https://doi.org/10.1016/j.ijhm.2011.02.001

Chen, Y.-C., Chiu, Y.-H., Huang, C.-W., \& Tu, C. H. (2013). The analysis of bank business performance and market risk - Applying Fuzzy DEA. Economic Modelling, 32, 225-232. https://doi.org/10.1016/j.econmod.2013.02.008

Chernikov, V., Kushch, S., \& Tikkanen, H. (2015). Customer empowerment and firm performance: Benefits and potential harm. In K. Kubacki (Ed.), Ideas in marketing: Finding the New and polishing the old (p. 138). Springer. https://doi.org/10.1007/978-3-319-10951-0_48

Child, J. (1974). Managerial and organizational factors associated with company performance part I. Journal of Management Studies, 11(3), 175-189. https://doi.org/10.1111/j.1467-6486.1974.tb00693.x

Claessens, S., \& Horen, N. (2014). Foreign banks: Trends and impact. Journal of Money, Credit and Banking, 46(s1), 295-326. https://doi.org/10.1111/jmcb.12092

Cooper, D. J., Ezzamel, M., \& Qu, S. Q. (2017). Popularizing a management accounting idea: The case of the balanced scorecard. Contemporary Accounting Research, 34(2), 991-1025. https://doi.org/10.1111/1911-3846.12299

Curtis, A., Li, V., \& Patrick, P. H. (2018). The use of adjusted earnings in performance evaluation. SSRN. https://doi.org/10.2139/ssrn.2682652

Danesh Asgari, S., Haeri, A., \& Jafari, M. (2017). Integration of balanced scorecard and three-stage data envelopment analysis approaches. Iranian Journal of Management Studies, 10(2), 527-550. 
Dash, M. (2017). A Model for bank performance measurement integrating multivariate factor structure with multi-criteria PROMETHEE methodology. Asian Journal of Finance \& Accounting, 9(1), 310-332. https://doi.org/10.5296/ajfa.v9i1.11073

Diamantini, C., Potena, D., \& Storti, E. (2016). Extended drill-down operator: Digging into the structure of performance indicators. Concurrency and Computation: Practice and Experience, 28(15), 3948-3968. https://doi.org/10.1002/cpe.3726

Dincer, H., \& Hacioglu, U. (2013). Performance evaluation with fuzzy VIKOR and AHP method based on customer satisfaction in Turkish banking sector. Kybernetes, 42(7), 1072-1085. https://doi.org/10.1108/K-02-2013-0021

Dinçer, H., Hacıoğlu, Ü., \& Yüksel, S. (2017). Balanced scorecard based performance measurement of European airlines using a hybrid multicriteria decision making approach under the fuzzy environment. Journal of Air Transport Management, 63, 17-33. https://doi.org/10.1016/j.jairtraman.2017.05.005

Emrouznejad, A., \& Anouze, A. L. (2010). Data envelopment analysis with classification and regression tree - a case of banking efficiency. Expert Systems, 27(4), 231-246. https://doi.org/10.1111/j.1468-0394.2010.00516.x

Emrouznejad, A., \& Yang, G. (2018). A survey and analysis of the first 40 years of scholarly literature in DEA: 1978-2016. Socio-Economic Planning Sciences, 61, 4-8. https://doi.org/10.1016/j.seps.2017.01.008

Fallah Jelodar, M. (2016). Prioritization of the factors affecting bank efficiency using combined data envelopment analysis and analytical hierarchy process methods. Journal of Optimization, 2016, 5259817. https://doi.org/10.1155/2016/5259817

Fan, L. W., Pan, S. J., Liu, G. Q., \& Zhou, P. (2017). Does energy efficiency affect financial performance? Evidence from Chinese energy-intensive firms. Journal of Cleaner Production, 151, 53-59. https://doi.org/10.1016/j.jclepro.2017.03.044

Faraglia, E., Marcet, A., \& Scott, A. (2008). Fiscal insurance and debt management in OECD economies. The Economic Journal, 118(527), 363-386. https://doi.org/10.1111/j.1468-0297.2007.02125.x

Feng, C.-M., \& Wang, R.-T. (2000). Performance evaluation for airlines including the consideration of financial ratios. Journal of Air Transport Management, 6(3), 133-142. https://doi.org/10.1016/S0969-6997(00)00003-X

Fornell, C., Morgeson III, F. V, \& Hult, G. T. M. (2016). Stock returns on customer satisfaction do beat the market: Gauging the effect of a marketing intangible. Journal of Marketing, 80(5), 92-107. https://doi.org/10.1509/jm.15.0229

Franklin-Johnson, E., Figge, F., \& Canning, L. (2016). Resource duration as a managerial indicator for Circular Economy performance. Journal of Cleaner Production, 133, 589-598. https://doi.org/10.1016/j.jclepro.2016.05.023

Gannon, B., Jones, C., McCabe, A., O’sullivan, R., \& Wakai, A. (2017). An economic cost analysis of emergency department key performance indicators in Ireland. European Journal of Emergency Medicine, 24(3), 196-201. https://doi.org/10.1097/MEJ.0000000000000347

Gërguri-Rashiti, S., Ramadani, V., Abazi-Alili, H., Dana, L., \& Ratten, V. (2017). ICT, innovation and firm performance: The transition economies context. Thunderbird International Business Review, 59(1), 93-102. https://doi.org/10.1002/tie.21772

Guo, H., Zhao, Y., Niu, T., \& Tsui, K.-L. (2017). Hong Kong Hospital Authority resource efficiency evaluation: Via a novel DEA-Malmquist model and Tobit regression model. PloS One, 12(9), e0184211. https://doi.org/10.1371/journal.pone.0184211

Ha, M.-H., \& Yang, Z. (2017). Comparative analysis of port performance indicators: Independency and interdependency. Transportation Research Part A: Policy and Practice, 103, 264-278.

https://doi.org/10.1016/j.tra.2017.06.013 
Hachicha, M., Fahad, M., Moalla, N., \& Ouzrout, Y. (2016). Performance assessment architecture for collaborative business processes in BPM-SOA-based environment. Data \& Knowledge Engineering, 105, 73-89. https://doi.org/10.1016/j.datak.2015.12.002

Hu, Y., Wen, J., \& Yan, Y. (2015). Measuring the performance of knowledge resources using a value perspective: integrating BSC and ANP. Journal of Knowledge Management, 19(6), 1250-1272. https://doi.org/10.1108/JKM-10-2014-0431

Huang, A., \& Badurdeen, F. (2017). Sustainable manufacturing performance evaluation: Integrating product and process metrics for systems level assessment. Procedia Manufacturing, 8, 563-570. https://doi.org/10.1016/j.promfg.2017.02.072

Kala, D., \& Bagri, S. C. (2016). Designing the strategy map for hotels with key performance indicators of balanced scorecard using DEMATEL technique. International Journal of Business Excellence, 10(2), 240-263. https://doi.org/10.1504/IJBEX.2016.078005

Kanyurhi, E. B., \& Bugandwa Mungu Akonkwa, D. (2016). Internal marketing, employee job satisfaction, and perceived organizational performance in microfinance institutions. International Journal of Bank Marketing, 34(5), 773-796. https://doi.org/10.1108/IJBM-06-2015-0083

Kaplan, R. S., \& Norton, D. P. (1992). The balanced scorecard œ measures that drive performance. Harvard Business Review, (January-February).

Kaplan, R. S., \& Norton, D. P. (1996a). Linking the balanced scorecard to strategy. California Management Review, 39(1), 53-79. https://doi.org/10.2307/41165876

Kaplan, R. S., \& Norton, D. P. (1996b). Strategic learning \& the balanced scorecard. Strategy \& Leadership, 24(5), 18-24. https://doi.org/10.1108/eb054566

Kaplan, R. S., \& Norton, D. P. (1996c). The balanced scorecard: translating strategy into action. Harvard Business Press.

Karbassi Yazdi, A., \& Abdi, F. (2017). Designing robust model for banks benchmarking based on Rembrandt method and DEA. Benchmarking: An International Journal, 24(2), 431-444. https://doi.org/10.1108/BIJ-01-2015-0001

Kaya, T. (2018). Monitoring brand performance based on household panel indicators using a fuzzy rank-based ORESTE methodology. Journal of Multiple-Valued Logic \& Soft Computing, 31, 443-467.

Kerai, S., \& Saleh, A. (2017). Applying the balanced scorecard to improve student satisfaction, market share and profitability. The Applied Management Review, 1(1), 27-38.

Keršulienė, V., \& Turskis, Z. (2011). Integrated fuzzy multiple criteria decision making model for architect selection. Technological and Economic Development of Economy, 17(4), 645-666. https://doi.org/10.3846/20294913.2011.635718

Keršuliene, V., Zavadskas, E. K., \& Turskis, Z. (2010). Selection of rational dispute resolution method by applying new step-wise weight assessment ratio analysis (SWARA). Journal of Business Economics and Management, 11(2), 243-258. https://doi.org/10.3846/jbem.2010.12

Kim, Y. H., \& Kim, M. (2010). A new approach for assessment and comparison of websites: Using the modified balanced scorecard and analytical hierarchy process. Journal of Hospitality Marketing \& Management, 19(6), 676-695. https://doi.org/10.1080/19368623.2010.493089

Kumar, M., \& Vincent, C. (2011). Benchmarking Indian banks using DEA in post-reform period: A progressive time-weighted mean approach. The Service Industries Journal, 31(14), 2455-2485. https://doi.org/10.1080/02642069.2010.504818

Kumar, P., Singh, R. K., \& Vaish, A. (2017). Suppliers' green performance evaluation using fuzzy extended ELECTRE approach. Clean Technologies and Environmental Policy, 19(3), 809-821. https://doi.org/10.1007/s10098-016-1268-y

LaPlante, A. E., \& Paradi, J. C. (2015). Evaluation of bank branch growth potential using data envelopment analysis. Omega, 52, 33-41. https://doi.org/10.1016/j.omega.2014.10.009 
Lazzarotti, V., Manzini, R., \& Mari, L. (2011). A model for R\&D performance measurement. International Journal of Production Economics, 134(1), 212-223. https://doi.org/10.1016/j.ijpe.2011.06.018

Lee, P. T.-W., Lin, C.-W., \& Shin, S.-H. (2018). Financial performance evaluation of shipping companies using entropy and grey relation analysis. In Multi-Criteria decision making in maritime studies and logistics (pp. 219-247). Springer. https://doi.org/10.1007/978-3-319-62338-2_9

Lee, S., Brownlee, E., Kim, Y., \& Lee, S. (2017). Ticket sales outsourcing performance measures using balanced scorecard and analytic hierarchy process combined model. Sport Marketing Quarterly; Morgantown, 26(2), 110-120.

Lerner, J., Schoar, A., Sokolinski, S., \& Wilson, K. (2018). The globalization of angel investments: Evidence across countries. Journal of Financial Economics, 127(1), 1-20. https://doi.org/10.1016/j.jfineco.2017.05.012

MacLeod, N. D., Ash, A. J., \& McIvor, J. G. (2004). An economic assessment of the impact of grazing land condition on livestock performance in tropical woodlands. The Rangeland Journal, 26(1), 49-71. https://doi.org/10.1071/RJ04004

Majumdar, S., \& Asgari, B. (2017). Performance analysis of listed companies in the UAE-using DEA Malmquist Index Approach. American Journal of Operations Research, 7(02), 133-151. https://doi.org/10.4236/ajor.2017.72010

Malagueño, R., Lopez-Valeiras, E., \& Gomez-Conde, J. (2018). Balanced scorecard in SMEs: Effects on innovation and financial performance. Small Business Economics, 51(1), 221-244. https://doi.org/10.1007/s11187-017-9921-3

Mardani, A., Nilashi, M., Zakuan, N., Loganathan, N., Soheilirad, S., Saman, M. Z. M., \& Ibrahim, O. (2017). A systematic review and meta-Analysis of SWARA and WASPAS methods: Theory and applications with recent fuzzy developments. Applied Soft Computing, 57, 265-292. https://doi.org/10.1016/j.asoc.2017.03.045

Mehralian, G., Nazari, J. A., Nooriparto, G., \& Rasekh, H. R. (2017). TQM and organizational performance using the balanced scorecard approach. International Journal of Productivity and Performance Management, 66(1), 111-125. https://doi.org/10.1108/IJPPM-08-2015-0114

Mwencha, M., Rosen, J. E., Spisak, C., Watson, N., Kisoka, N., \& Mberesero, H. (2017). Upgrading supply chain management systems to improve availability of medicines in Tanzania: Evaluation of performance and cost effects. Global Health: Science and Practice, 5(3), 399-411. https://doi.org/10.9745/GHSP-D-16-00395

Nielsen, E. H., \& Nielsen, S. (2018). System Dynamics Modeling, its concept of causality and particular relevance for providing the Balanced Scorecard thinking with a dynamic analytical framework. Aarhus.

Ozkan, N., Cakan, S., \& Kayacan, M. (2017). Intellectual capital and financial performance: A study of the Turkish Banking Sector. Borsa Istanbul Review, 17(3), 190-198. https://doi.org/10.1016/j.bir.2016.03.001

Paradi, J. C., Rouatt, S., \& Zhu, H. (2011). Two-stage evaluation of bank branch efficiency using data envelopment analysis. Omega, 39(1), 99-109. https://doi.org/10.1016/j.omega.2010.04.002

Paradi, J. C., \& Zhu, H. (2013). A survey on bank branch efficiency and performance research with data envelopment analysis. Omega, 41(1), 61-79. https://doi.org/10.1016/j.omega.2011.08.010

Patiar, A., \& Wang, Y. (2016). The effects of transformational leadership and organizational commitment on hotel departmental performance. International Journal of Contemporary Hospitality Management, 28(3), 586-608. https://doi.org/10.1108/IJCHM-01-2014-0050

Podgórski, D. (2015). Measuring operational performance of OSH management system - A demonstration of AHP-based selection of leading key performance indicators. Safety Science, 73, 146-166. https://doi.org/10.1016/j.ssci.2014.11.018 
Rabbani, A., Zamani, M., Yazdani-Chamzini, A., \& Zavadskas, E. K. (2014). Proposing a new integrated model based on sustainability balanced scorecard (SBSC) and MCDM approaches by using linguistic variables for the performance evaluation of oil producing companies. Expert Systems with Applications, 41(16), 7316-7327. https://doi.org/10.1016/j.eswa.2014.05.023

Sedady, F., \& Beheshtinia, M. A. (2019). A novel MCDM model for prioritizing the renewable power plants' construction. Management of Environmental Quality: An International Journal, 30(2), 383399. https://doi.org/10.1108/MEQ-05-2018-0102

Sadeghi, M., Razavi, S. H., \& Saberi, N. (2013). Application of grey TOPSIS in preference ordering of action plans in balanced scorecard and strategy map. Informatica, 24(4), 619-635. https://doi.org/10.15388/Informatica.2013.07

Saeidi, S. P., Sofian, S., Saeidi, P., Saeidi, S. P., \& Saaeidi, S. A. (2015). How does corporate social responsibility contribute to firm financial performance? The mediating role of competitive advantage, reputation, and customer satisfaction. Journal of Business Research, 68(2), 341-350.

https://doi.org/10.1016/j.jbusres.2014.06.024

Sainaghi, R., Phillips, P., \& d'Angella, F. (2018). The balanced scorecard of a new destination product: Implications for lodging and skiing firms. International Journal of Hospitality Management, 76 (Part A), 216-230. https://doi.org/10.1016/j.ijhm.2018.05.011

Šaparauskas, J., Kazimieras Zavadskas, E., \& Turskis, Z. (2011). Selection of facade’s alternatives of commercial and public buildings based on multiple criteria. International Journal of Strategic Property Management, 15(2), 189-203. https://doi.org/10.3846/1648715X.2011.586532

Shafiee, M., Lotfi, F. H., Saleh, H., \& Ghaderi, M. (2016). A mixed integer bi-level DEA model for bank branch performance evaluation by Stackelberg approach. Journal of Industrial Engineering International, 12(1), 81-91. https://doi.org/10.1007/s40092-015-0131-9

Shaverdi, M., Akbari, M., \& Tafti, S. F. (2011). Combining fuzzy MCDM with BSC approach in performance evaluation of Iranian private banking sector. Advances in Fuzzy Systems, 2011, 148712. https://doi.org/10.1155/2011/148712

Singh, S., Darwish, T. K., \& Potočnik, K. (2016). Measuring organizational performance: A case for subjective measures. British Journal of Management, 27(1), 214-224. https://doi.org/10.1111/14678551.12126

Sofiyabadi, J., Kolahi, B., \& Valmohammadi, C. (2016). Key performance indicators measurement in service business: a fuzzy VIKOR approach. Total Quality Management \& Business Excellence, 27(9-10), 1028-1042.

Sun, J., Wang, C., Ji, X., \& Wu, J. (2017). Performance evaluation of heterogeneous bank supply chain systems from the perspective of measurement and decomposition. Computers \& Industrial Engineering, 113, 891-903. https://doi.org/10.1016/j.cie.2017.05.028

Sundharam, V. N., Sharma, V., \& Stephan Thangaiah, I. S. (2013). An integration of BSC and AHP for sustainable growth of manufacturing industries. International Journal of Business Excellence, 6(1), 77-92. https://doi.org/10.1504/IJBEX.2013.050577

Tan, H. X., Yeo, Z., Ng, R., Tjandra, T. B., \& Song, B. (2015). A sustainability indicator framework for Singapore small and medium-sized manufacturing enterprises. Procedia Cirp, 29, 132-137. https://doi.org/10.1016/j.procir.2015.01.028

Tayeh, M., Al-Jarrah, I. M., \& Tarhini, A. (2015). Accounting vs. market-based measures of firm performance related to information technology investments. International Review of Social Sciences and Humanities, 9(1), 129-145.

Torkzad, A., \& Beheshtinia, M. A. (2019). Evaluating and prioritizing hospital service quality. International Journal of Health Care Quality Assurance, 32(2), 332-346.

https://doi.org/10.1108/IJHCQA-03-2018-0082 
Valmohammadi, C., \& Sofiyabadi, J. (2015). Modeling cause and effect relationships of strategy map using fuzzy DEMATEL and fourth generation of balanced scorecard. Benchmarking: An International Journal, 22(6), 1175-1191. https://doi.org/10.1108/BIJ-09-2014-0086

Van der Westhuizen, G. (2008). Estimating technical and scale efficiency and sources of efficiency change in banks using balance sheet data: A South African study. Studies in Economics and Econometrics, 32(1), 23-46.

Varmazyar, M., Dehghanbaghi, M., \& Afkhami, M. (2016). A novel hybrid MCDM model for performance evaluation of research and technology organizations based on BSC approach. Evaluation and Program Planning, 58, 125-140. https://doi.org/10.1016/j.evalprogplan.2016.06.005

Vilanova, M. R. N., Magalhães Filho, P., \& Balestieri, J. A. P. (2015). Performance measurement and indicators for water supply management: Review and international cases. Renewable and Sustainable Energy Reviews, 43, 1-12. https://doi.org/10.1016/j.rser.2014.11.043

Wu, J., Zhu, Q., Yin, P., \& Song, M. (2017). Measuring energy and environmental performance for regions in China by using DEA-based Malmquist indices. Operational Research, 17(3), 715-735. https://doi.org/10.1007/s12351-015-0203-Z

Yang, C., \& Liu, H.-M. (2012). Managerial efficiency in Taiwan bank branches: A network DEA. Economic Modelling, 29(2), 450-461. https://doi.org/10.1016/j.econmod.2011.12.004

Yazdi, A. K., Wang, Y. J., \& Alirezaei, A. (2018). Analytical insights into firm performance: a fuzzy clustering approach for data envelopment analysis classification. International Journal of Operational Research, 33(3), 413-429. https://doi.org/10.1504/IJOR.2018.095630

Zahoor, A., \& Sahaf, M. A. (2018). Investigating causal linkages in the balanced scorecard: an Indian perspective. International Journal of Bank Marketing, 36(1), 184-207. https://doi.org/10.1108/IJBM-09-2016-0128

Zavadskas, E. K., Antucheviciene, J., Saparauskas, J., \& Turskis, Z. (2013). MCDM methods WASPAS and MULTIMOORA: verification of robustness of methods when assessing alternative solutions. Economic Computation and Economic Cybernetics Studies and Research, 47(2), 5-20.

Zavadskas, E. K., Antucheviciene, J., Šaparauskas, J., \& Turskis, Z. (2013). Multi-criteria assessment of facades' alternatives: peculiarities of ranking methodology. Procedia Engineering, 57, 107-112. https://doi.org/10.1016/j.proeng.2013.04.016

Zavadskas, E. K., Turskis, Z., Antucheviciene, J., \& Zakarevicius, A. (2012). Optimization of weighted aggregated sum product assessment. Elektronika ir Elektrotechnika, 122(6), 3-6. https://doi.org/10.5755/j01.eee.122.6.1810

Zhao, H., \& Li, N. (2015). Evaluating the performance of thermal power enterprises using sustainability balanced scorecard, fuzzy Delphic and hybrid multi-criteria decision making approaches for sustainability. Journal of Cleaner Production, 108(Part A), 569-582. https://doi.org/10.1016/j.jclepro.2015.07.141

Zolfani, S. H., \& Ghadikolaei, A. S. (2013). Performance evaluation of private universities based on balanced scorecard: empirical study based on Iran. Journal of Business Economics and Management, 14(4), 696-714. https://doi.org/10.3846/16111699.2012.665383 